\title{
GYPSUM KARST AND POTENTIAL RISK IN SITING WIND TURBINES IN BLAINE COUNTY, OKLAHOMA
}

\author{
Kenneth S. Johnson \\ Oklahoma Geological Survey, 1321 Greenbriar Dr., Norman, OK 73072, USA, ksjohnson@ou.edu \\ William J. Bangsund \\ Barr Engineering Co., 4700 W. 77 Street, Minneapolis, MN 55435, USA, BBangsund@barr.com
}

\author{
Neal A. Hines \\ ENVIRON International, Austin, TX, nhines@environcorp.com
}

\begin{abstract}
Gypsum, a highly soluble rock, is readily dissolved to form karst features identical to those associated with limestones and dolomites. Investigations in Blaine County, in northwestern Oklahoma, evaluated potential problems that subsidence due to gypsum karst may pose for the proposed Watonga Wind-Power Project, a wind-turbine project just east of Watonga. Catastrophic collapse of a wind turbine is clearly unacceptable, and minor settlement could also be a risk. Differential settlement by even $3 \mathrm{~cm}$ across a 15-m-wide turbine foundation could lead to the turbine tilting out of tolerance, requiring remedial repairs.
\end{abstract}

Gypsum beds of the Permian Blaine Formation underlie all parts of the Project Area, at depths ranging from 10 to $45 \mathrm{~m}$ below ground level. The Blaine Formation here is about $29 \mathrm{~m}$ thick: it consists of four gypsum beds, each 0.6 to $4 \mathrm{~m}$ thick, interbedded mainly with red-brown shales. The Blaine is overlain by the Permian Dog Creek Shale and by unconsolidated Quaternary sands, clays, and gravels that may obscure karst features. Field studies, aerial-photo analysis, and literature review show that there is no evidence of gypsum karst in the Project Area.

Although lacking direct evidence of karst in or near the Project Area, we recognize there is some potential for subsidence due to dissolution of shallow gypsum. Additional mitigation of this risk can be achieved by placing wind turbines at sites where the gypsum beds are deepest: we believe that where gypsum is $25 \mathrm{~m}$ below ground level, or deeper, the risk related to gypsum karst is low. Placing turbines at sites where gypsum beds are less than $25 \mathrm{~m}$ deep would pose a medium or high risk. To minimize this risk, a map was prepared showing areas of low, medium, and high risk, related to potential gypsum karst.

\section{Introduction}

This study examines the surface and subsurface geology of an area just east of Watonga, in Blaine County, northwestern Oklahoma (Figure 1). The study area embraces nearly $400 \mathrm{~km}^{2}$, including the $140-\mathrm{km}^{2}$ Watonga Wind-Power Project Area wherein approximately 160 wind turbines would be constructed. The study focuses on the thickness, distribution, structure, and depth of gypsum beds in the Permian Blaine Formation that underlie the Project Area.

Gypsum is a highly soluble rock. Generally, it is susceptible to being partially or totally dissolved by

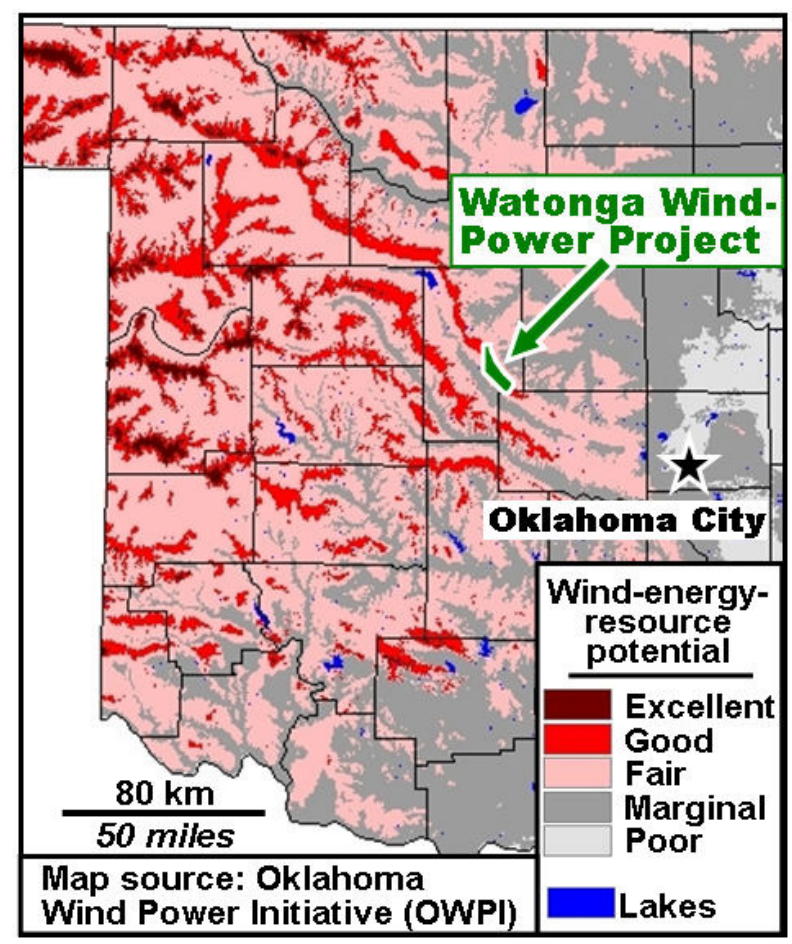

Figure 1. Map of western Oklahoma showing location of Watonga Wind-Power Project and the windenergy-resource potential at $50 \mathrm{~m}$ above ground level. 
groundwater, and to developing karst features such as caves, sinkholes, and underground water courses that commonly are also found in limestones and dolomites (Martinez and others, 1998; Johnson, 2003a, 2008). Gypsum beds crop out just east of the Project Area, and dip gently to the southwest where they underlie all parts of the Project Area. Because of the potential for gypsum karst in western Oklahoma, the distribution and depth of the various gypsum beds is important in the siting of wind turbines because of the potential for collapse due to subsurface bedrock dissolution. A wind turbine located above a sinkhole, cave, or other karst feature could become unstable if there is any settlement of the ground.

The depth to the top of the uppermost gypsum in the Blaine Formation ranges from 10 to $45 \mathrm{~m}$, and in most of the Project Area the depth is 25 to $35 \mathrm{~m}$. We believe that where the depth is $25 \mathrm{~m}$ or more, such a site would pose a low risk for problems related to gypsum karst, because if there is karst in these Blaine gypsum beds below that depth it is unlikely that subsidence would reach up to and impact the land surface. We believe that karst in the Blaine gypsums at shallower depths would pose a higher risk for a wind turbine.

Western Oklahoma is a favorable area for windgenerated energy (Figure 1). According to the Oklahoma Department of Commerce (personal correspondence, 2012), as of May 2012 there are 20 wind projects operating in western Oklahoma, with a generating capacity of about 2300 megawatts, and an additional 5 projects are under construction, with a capacity of nearly 900 megawatts.

\section{Geologic Setting}

Outcrops of Permian rocks in the Watonga area include gypsum and shale beds of the Blaine Formation, overlain by the Dog Creek Shale (Figures 2, 3, 4). These are, in turn, overlain by Quaternary terrace deposits and alluvium. The Blaine Formation is about $29 \mathrm{~m}$ thick in the Watonga area, and individual beds of white gypsum range from 0.6 to $4 \mathrm{~m}$ thick (Fay and others, 1962; Fay 1964). Gypsum typically makes up about $25 \%$ of the formation; the remainder is mostly red-brown shale and several thin beds of dolomite. The thickest gypsum is the 4-m-thick Shimer Gypsum Bed at the top of the formation. The Blaine Formation dips gently to the south and southwest, beneath the Project Area, at a rate of about 2 to $4 \mathrm{~m} / \mathrm{km}$ (about 0.1 to 0.2 degree).

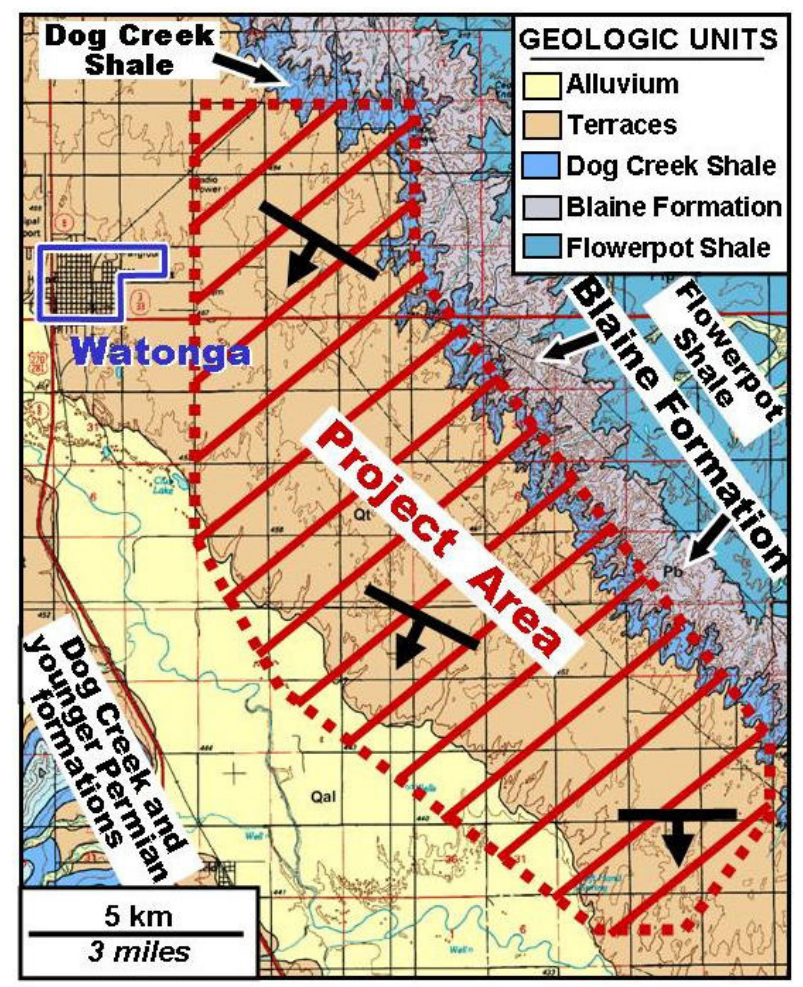

Figure 2. Geologic map of the Watonga WindPower Project Area in Blaine County (Fay, 2010). Blaine Formation gypsum beds dip gently to the south and southwest (the strike and dip symbols) beneath the Dog Creek Shale and Terrace Deposits that mantle most of the Project Area.

The Dog Creek Shale generally is 50 to $58 \mathrm{~m}$ thick in Blaine County (Fay and others, 1962; Fay, 1964), but the upper part is eroded in the Project Area and only about 3 to $15 \mathrm{~m}$ of shale remains. The Dog Creek is principally red-brown shale (upper part of Figure 3), but it contains several thin beds of gypsum ( 0.5 to $2 \mathrm{~m}$ thick) in the subsurface southwest of the Project Area.

Above the Dog Creek Shale are Quaternary terrace deposits and alluvium deposited by the North Canadian River. They consist of non-cemented sands, clays, and gravels that generally are 10 to $20 \mathrm{~m}$ thick. All of the proposed wind turbines will be sited directly upon these Quaternary deposits where they overlie the Dog Creek Shale.

\section{Methods of Study}

A comprehensive review of the geologic literature to determine if karst features have been reported in Blaine County and nearby parts of Oklahoma was carried out. An aerial-photo study was also conducted to detect any possible karst features. Nearby outcrops of gypsum were 


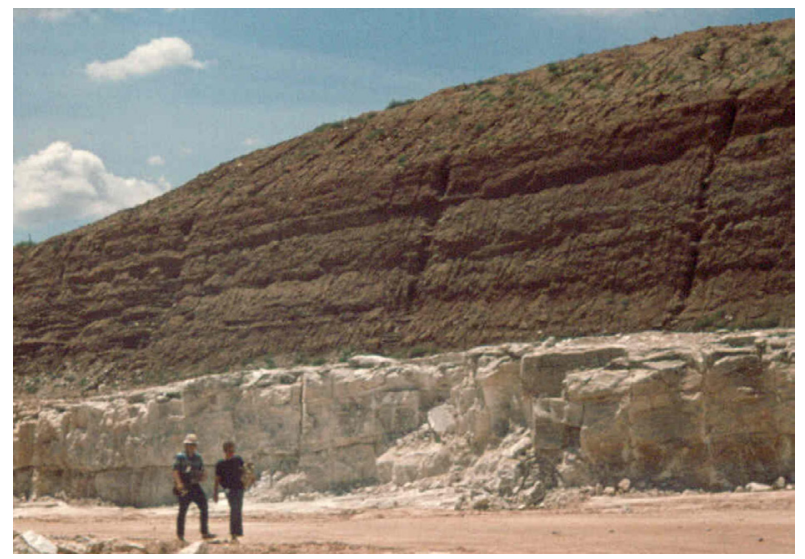

Figure 3. Exposure of the Shimer Gypsum Bed (white) at top of Blaine Formation and the overlying Dog Creek Shale (redbeds). Exposed in US Gypsum quarry about $20 \mathrm{~km}$ north of Watonga. Gypsum here is $4.5 \mathrm{~m}$ thick.

also visited to determine if there is any field evidence of karst features in or near the Project Area.

Additionally, electrical logs (also called "geophysical logs") of many petroleum test wells drilled within and near the Project Area were examined, 20 of which contained near-surface data on the thickness and depth of individual Blaine gypsum beds. The electric-log study enabled compiling a structure-contour map on the Shimer Gypsum Bed at the top of the Blaine Formation, and this was used to determine the depth to the top of the Blaine Formation gypsum beds beneath the Project Area.
Using all these studies and data, we compiled a "riskcategories” map (discussed below) to help minimize the possibility that gypsum karst will have an adverse impact on any part of the Project.

\section{Literature Review}

A State geologic map was prepared by Miser (1954), followed by detailed maps of the surface geology of Blaine County and the Watonga area by Fay and others (1962) and Fay (2010). These later maps show the outcrop area of gypsum beds in the Blaine Formation, as well as outcrops of the overlying Dog Creek Shale and the Quaternary-age terrace deposits and alluvium (Figure 2). In addition, Fay (1964) discussed the stratigraphy and character of the Blaine Formation and associated strata throughout northwestern Oklahoma. These three studies by Fay were most valuable for understanding the geology of the Project Area (see “Geologic Setting” above).

Gypsum karst has been described in thicker gypsum beds elsewhere in western Oklahoma by Myers and others (1969), Johnson (1989, 1990, 2003b), and Bozeman (2003). In addition, a number of gypsum caves in the Blaine Formation of western Oklahoma have been examined, mapped, and described by John and Sue Bozeman, of the Central Oklahoma Grotto, Oklahoma City: these reports have been released in Oklahoma Underground, which is a serial publication of the Central Oklahoma Grotto. As spelunking experts

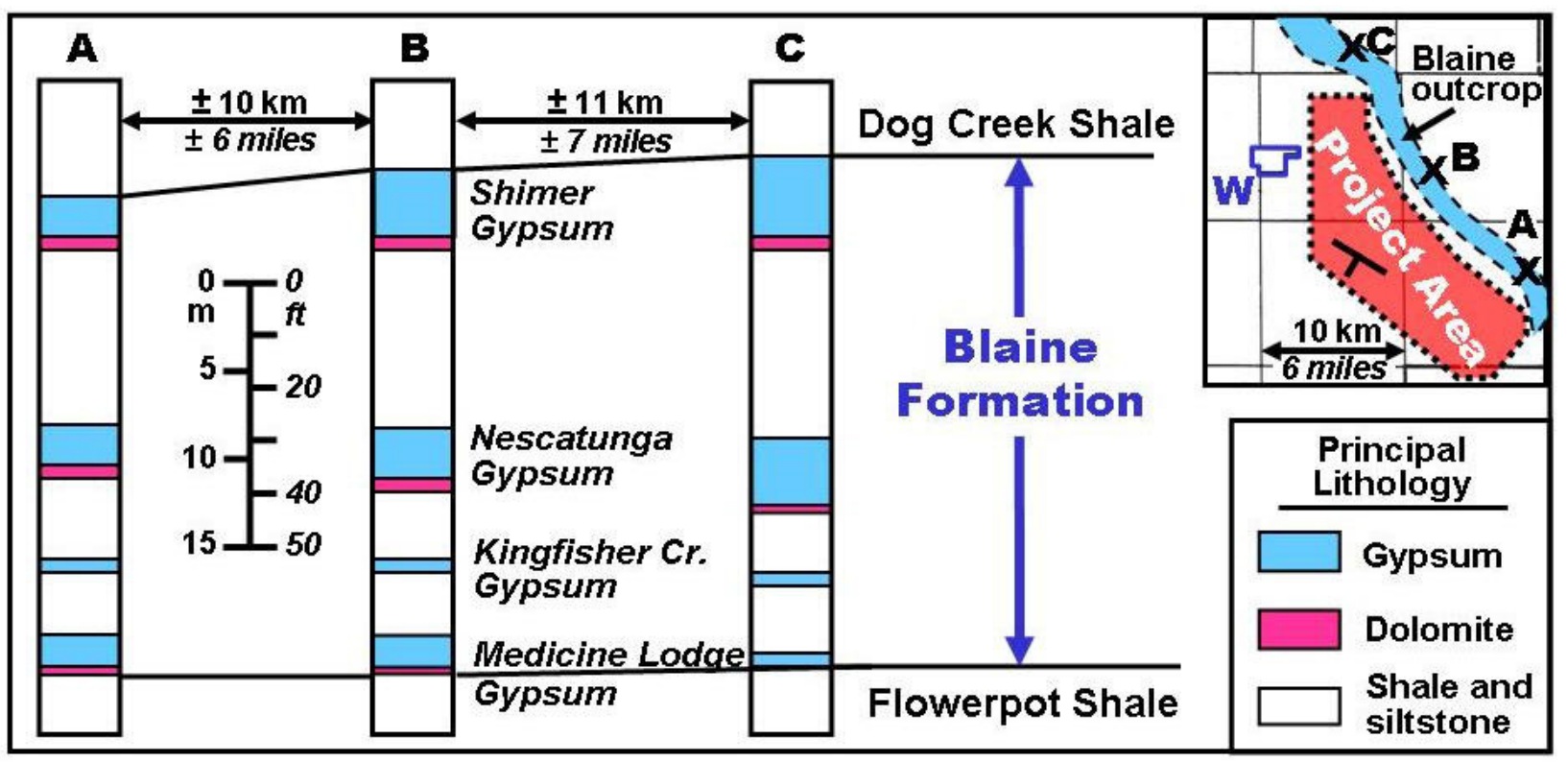

Figure 4. Cross section showing thickness of gypsum beds of the Permian Blaine Formation in outcrops just east of the Watonga Wind-Power Project Area (after Fay and others, 1962). View looking to the southwest. 
on gypsum caves of western Oklahoma, John and Sue Bozeman reported that they are not aware of any caves in the vicinity of the Watonga Wind-Project Area (personal communication, 2010).

Gypsum karst has not been recognized or described in the Project Area in any of the literature, probably because the gypsum beds here are quite thin and are interbedded with thicker, low-permeability shales that inhibit groundwater access to the gypsums. The one feature showing possible evidence of gypsum karst is the Foley sink, that formed $6.5 \mathrm{~km}$ west of the northwest corner of the Project Area in 1957 (Fay, 1958). The sink formed in Quaternary terrace deposits, about $30 \mathrm{~m}$ above the top of the Blaine Formation. Originally about $15 \mathrm{~m}$ wide and $5 \mathrm{~m}$ deep, the sinkhole has been filled by the landowner. No studies have been carried out to determine the true cause of the sinkhole. Fay also mentioned several older sinks located about 225 m northeast of Foley sink.

A statewide, general assessment of potential karst terrains in Oklahoma was made by Johnson (2003c). The study was preliminary, with only general data discussing the various potentially karstic rocks (limestone, dolomite, gypsum, and salt), and showing the general outcrop area of Blaine gypsums in northwest Oklahoma.

\section{Aerial-Photo Study}

Personnel at Barr Engineering in Minneapolis, MN, examined aerial photos of the Project Area taken in 2006 and stereo-image pairs from three dates (May 2006; November 1990; and April 1979). A number of linear drainage features are evident that extend in directions between $\mathrm{N} 20^{\circ} \mathrm{E}$ and $\mathrm{N} 30^{\circ} \mathrm{E}$ (oriented northeast to southwest), but field examination did not show that these features are related to sinkholes or voids.

The aerial-photo study also identified some ephemeral ponds as "potential sinkholes," but field studies did not confirm any evidence of sinkholes. Many closed depressions are present in the Quaternary terrace deposits that blanket the area. Inasmuch as these terrace deposits contain much wind-blown sand and silt, the land surface consists of many sand dunes that create a hummocky topography, with internal drainage flowing into many small depressions. Some of these depressions, at first glance, may appear to be related to sinkhole development or collapse structures, but there is no evidence that any of the small depressions have, in fact, resulted from ground collapse. The small ephemeral ponds present in some of the depressions appear to result from local runoff (from precipitation) into areas that have no external drainage.

\section{Field Examination}

Field studies have discounted the presence of "potential sinkholes" in terrace deposits, as suggested in the earlier aerial-photo study (see above). Also, gypsum exposures in outcrops and quarries near the Project Area were examined, and no evidence of karst features or voids was found. This observation agrees with the earlier findings of Fay and others (1962) and Fay (1964), and with recent discussions with John and Sue Bozeman (personal communication, 2010). The one exception is the Foley sink, described above, that is 6.5 $\mathrm{km}$ west of the Project Area. The Foley sink has been backfilled by the landowner and now is just a gentle depression in the ground.

\section{Electric-Log Study}

About 400 petroleum tests have been drilled in, and adjacent to, the Project Area. The electric logs of these wells were examined by Johnson, but only 20 of them contained data about the Blaine Formation or other rock layers present in the top $100 \mathrm{~m}$ of the borehole. Recognition of gypsum beds and associated rock types on electric logs is well established (Alger and Crain, 1966), and the senior author has conducted many studies using various types of well logs to identify, correlate, and map gypsum beds in the subsurface-some of the studies are in public documents (Johnson, 1967, 1985, 1993), and many others are in consulting reports.

On each of the 20 useable electric logs in the study area, individual gypsum beds (and interbedded shale units) that are at least $0.5 \mathrm{~m}$ thick can be identified readily (Figure 5). Recognition and identification of gypsum beds on the electric logs is confirmed by comparison and correlation with outcrops (Figure 4) just $3 \mathrm{~km}$ to the northeast. Correlation from outcrops to the electric logs shows that the overall thickness of the Blaine Formation, as well as the thickness of individual units, is quite uniform beneath the Project Area.

The principal result of the electric-log study is preparation of a structure-contour map that shows the elevation of the top of the uppermost gypsum (the Shimer Gypsum) of the Blaine Formation beneath the Project Area (Figure 6). 


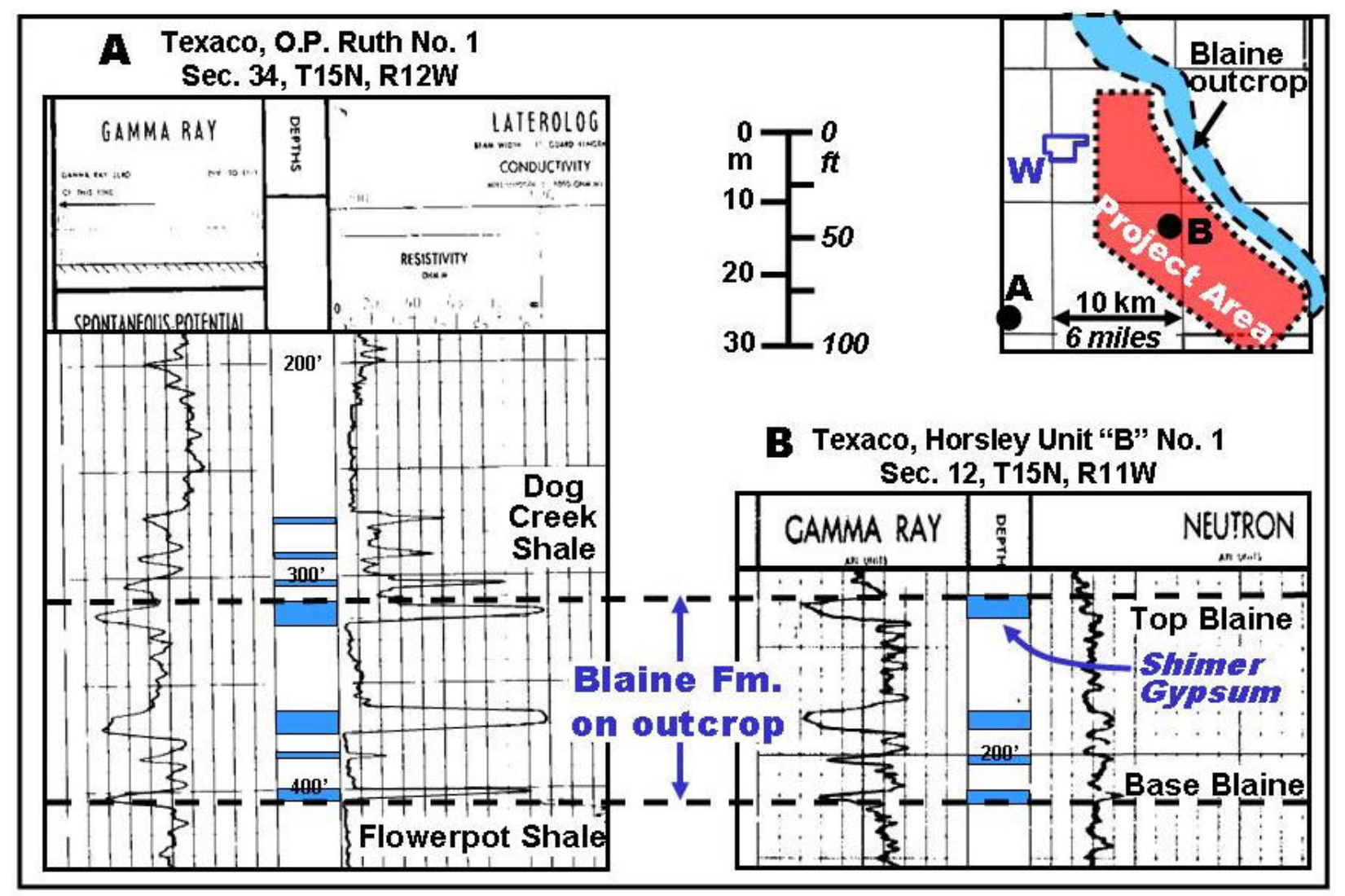

Figure 5. Electric logs of two wells showing depths (in feet) and log characteristics of gypsum beds in the Blaine Formation in (and near) the Watonga Wind-Power Project.

\section{Results of Study}

As a result of the foregoing studies, it is possible to use the structure-contour map and topographic maps to select sites for construction of wind turbines where the risk is low, with regard to possible gypsum karst.

\section{Potential Karst Risks}

Evaporite rocks, mainly gypsum (or anhydrite) and rock salt, are the most soluble of common rocks. They can be dissolved readily to form caves, sinkholes, and other karst features. Gypsum karst has not been documented in the Watonga area in the literature, probably because the gypsum beds here are quite thin and are interbedded with thicker, low-permeability shales that inhibit groundwater access to the gypsum. Evidence of gypsum karst would include surface and shallow-subsurface features, such as caves, sinkholes, disappearing streams, springs, collapse structures, and the dropping of drill bits and/or loss of drilling fluids while drilling through gypsum beds. None of these features have been found.
As in any project undertaken in areas of soluble rock, karst can pose risks to wind turbines. If gypsum karst is present beneath the Project Area, it could cause subsidence or settlement of the overlying Dog Creek Shale and Quaternary sediments. This could result in tilting of, or damage to, the foundation of a turbine built above the karst feature. Even differential settlement of 3 $\mathrm{cm}$ across a turbine foundation that is $15 \mathrm{~m}$ wide could cause the turbine to tilt and require remedial repairs.

Based upon literature review, field investigations, and our other studies, there is no evidence of gypsumkarst features in outcrops in the Watonga area, or in the shallow subsurface beneath the Project Area. However, to further reduce the potential risk of gypsum karst on the Project, we recommend that wind turbines be placed at sites where the top of the Blaine gypsum beds is at least $25 \mathrm{~m}$ below the land surface.

\section{Structure-Contour Map and Cross Section}

The structure-contour map (Figure 6) was made by plotting the elevation of the top of the Blaine Formation 


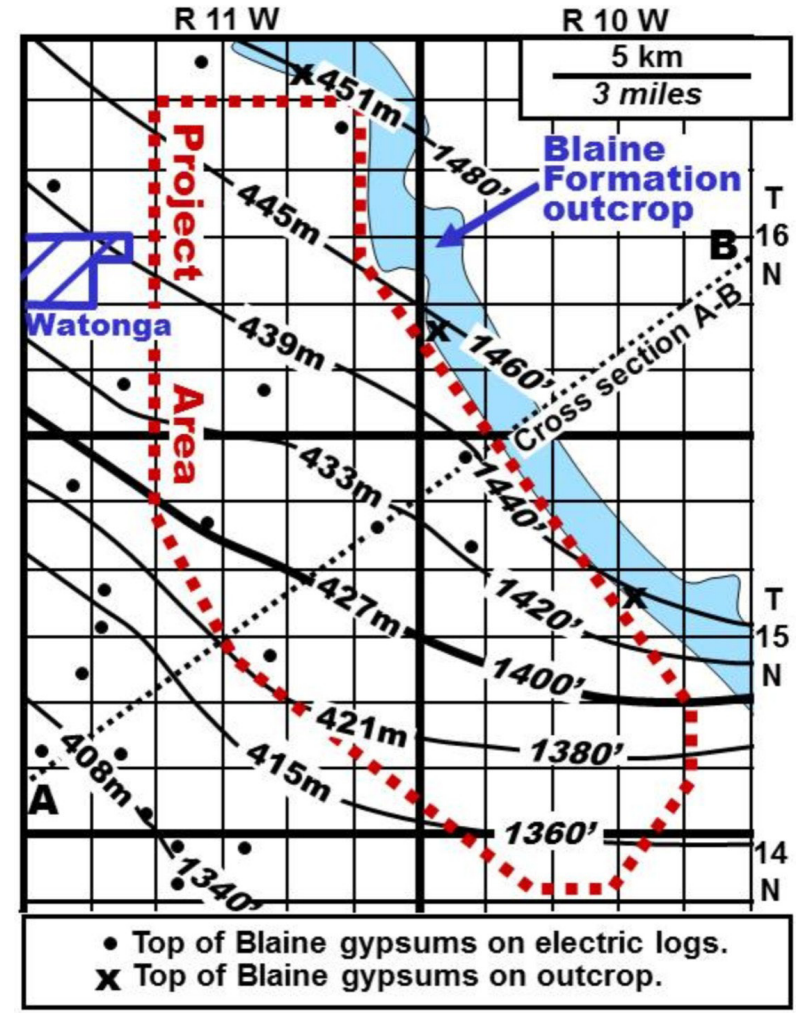

Figure 6. Structure-contour map showing elevation on top of the Blaine Formation gypsums beneath the Watonga Wind-Project Project Area. Contour interval is $6 \mathrm{~m}$ (20 feet). Cross section A—B shown on Figure 7.

on the outcrop and on electric logs of petroleum tests. The Blaine Formation dips gently and uniformly to the south and southwest at a rate of about 2 to $4 \mathrm{~m} / \mathrm{km}$ (about 0.1 to 0.2 degree). This map is most useful because it shows the approximate elevation of the uppermost gypsum bed (Shimer Gypsum) beneath all parts of the Project Area, and the Shimer elevation can be subtracted from the elevation of the land surface to determine the approximate depth to the top of the Shimer Gypsum. If there is a potential for gypsum-karst features to impact the Project, these features would most likely be present in the shallowest and thickest gypsum - the Shimer Gypsum Bed. But all evidence presented indicates that there is no karst present in the Project Area.

A cross section (Figure 7) shows subsurface relationships between the Blaine gypsums and the overlying Dog Creek Shale and the Quaternary terrace deposits and alluvium beneath the Project Area. The cross section is based on outcrop information from Fay and others (1962 and Figure 4), and on the structure map on top of the Blaine Formation (Figure 6). In all parts of the Project Area where turbines might be constructed, they would be located upon Quaternary terrace deposits or alluvium. Immediately beneath these Quaternary deposits, remnants of the lower Dog Creek Shale are present and would separate the Quaternary deposits from the Shimer Gypsum. The Dog Creek Shale is a low-permeability barrier that provides added protection against karst by inhibiting the flow of groundwater from Quaternary sediments into underlying gypsum beds.

\section{Risk Map}

Aschematic cross section shows possible karst conditions in gypsum, related to the depth of gypsum below the land

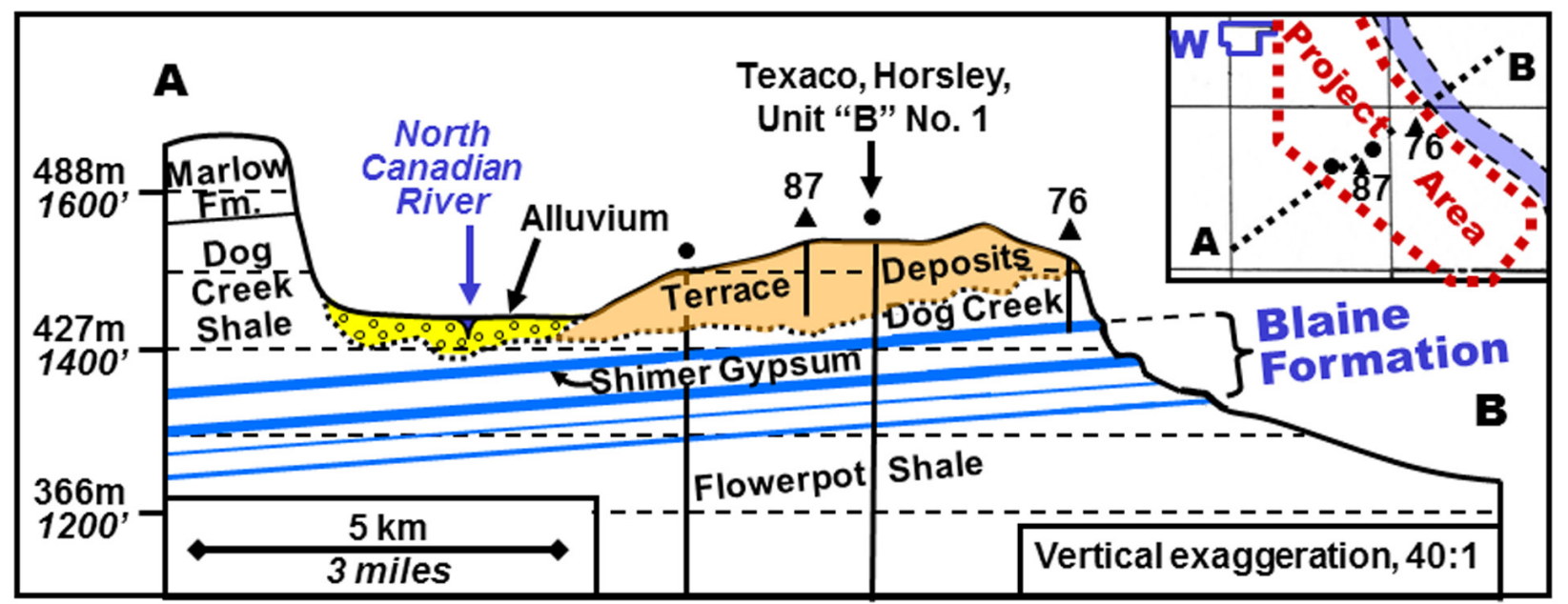

Figure 7. Cross section $A-B$ through the Watonga Wind-Power Project Area showing the dip of strata and depths of gypsum beds of the Blaine Formation. Cross section based upon: Figure 6; outcrop data; two borings by Barr Engineering Co. (borings \#87 and \#76); and electric logs of oil-well tests (including Texaco, Horsley Unit "B" No. 1, shown in Figure 5). Line of cross section shown on Figure 6. 


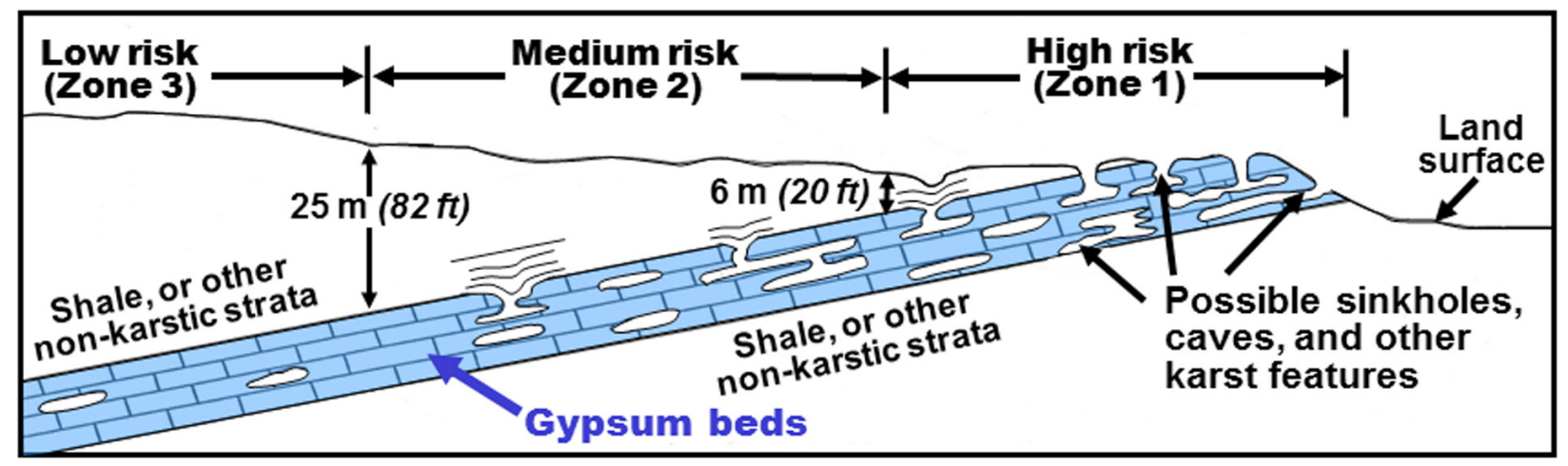

Figure 8. Schematic cross section showing low-, medium-, and high-risk karst zones, which are related to the depth of possible karstic gypsum in northwestern Oklahoma (modified from Johnson, 2003c).

surface (Figure 8). It is reasonable to expect that placing wind turbines at sites where the gypsum beds are $25 \mathrm{~m}$ deep, or deeper, would pose a low risk related to gypsum karst subsidence. Sites where the gypsum is more than $6 \mathrm{~m}$, but less than $25 \mathrm{~m}$, below the surface are sites of medium risk, and sites where the gypsum is $6 \mathrm{~m}$, or less, below the surface are sites of high risk.

Using criteria cited above (25- and 6-m depths to gypsum), a risk map (Figure 9) was prepared by Barr Engineering personnel using a GIS program that compared the elevation of the land surface with the elevation of the Blaine Formation (Figure 6). This established the depth to the top of the uppermost gypsum bed in all parts of the Project Area.

These gypsum-depth/risk categories are considered to be conservative. Although there is no evidence of gypsum karst in the Watonga area, it is possible that dissolution of gypsum has occurred and has not yet been identified. At least $25 \mathrm{~m}$ of sand, clay, gravel, and shale between a wind-turbine base and the shallowest gypsum bed should provide sufficient protection from possible karst development and collapse structures, and turbine sites in those areas would be at low risk. Using these criteria and the risk map, it will be possible to locate any proposed turbine site in the low-risk area, and the medium- and high-risk areas can be avoided.

In most parts of the Project Area the uppermost gypsum is 25 to $35 \mathrm{~m}$ deep, and locally it is up to $45 \mathrm{~m}$ deep. Therefore, most of the area is considered to pose a low risk for problems related to gypsum karst.

\section{Summary and Recommendations}

Gypsum beds of the Permian Blaine Formation underlie all parts of the Watonga Wind-Power Project Area.
Being a highly soluble rock, gypsum is readily dissolved to form karst features identical to those associated with limestones and dolomites. Settlement of a turbine foundation by even a couple of $\mathrm{cm}$ above gypsumkarst features could lead to tilting of the turbine out of tolerance and require remedial repairs. Therefore, we examined the local geology to evaluate whether gypsum karst could pose problems for the Project.

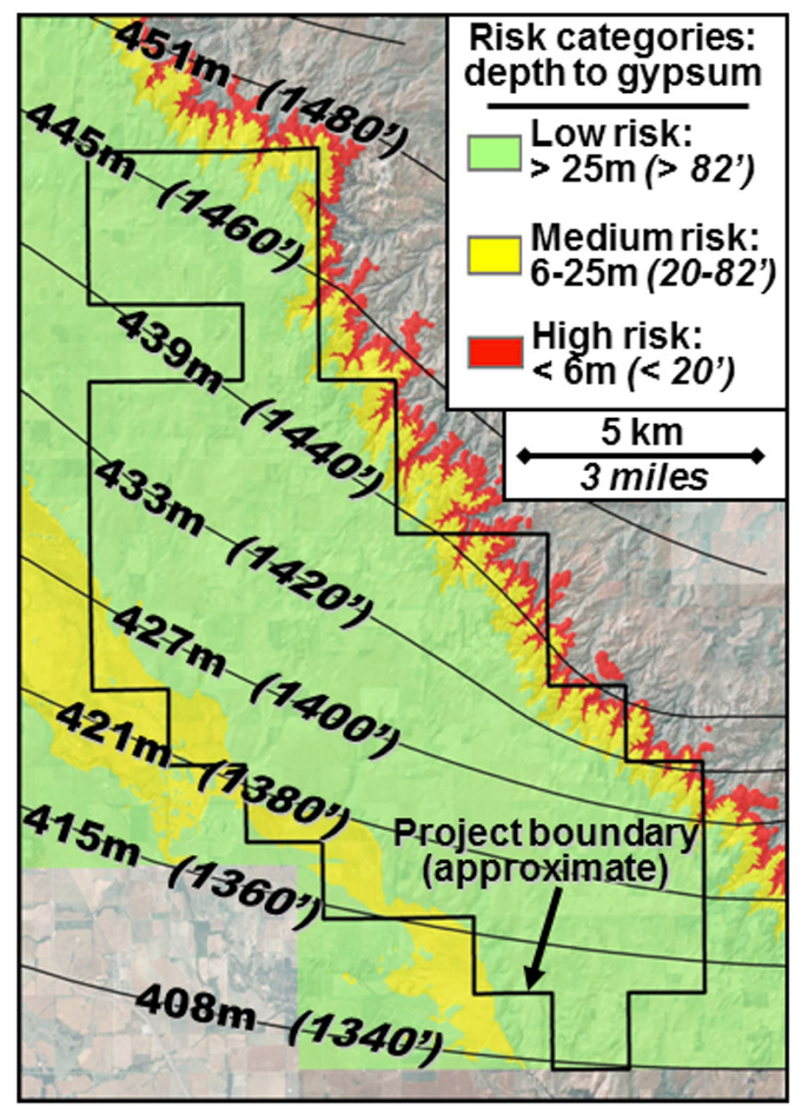

Figure 9. Risk categories at Watonga Wind-Power Project, based upon depth to the Shimer Gypsum at top of the Blaine Formation. Contour lines from Figure 6. 
The Blaine Formation is about 29 m thick, and consists of four gypsum beds, each 0.6 to $4 \mathrm{~m}$ thick. The top of the gypsums is 10 to $45 \mathrm{~m}$ below ground level in the Project Area. The Blaine is overlain by the Permian Dog Creek Shale and by unconsolidated Quaternary sands, clays, and gravels that may obscure karst features. Field studies, aerial-photo analysis, and literature study show that there is no direct evidence of gypsum karst in the Project Area.

Examination of electric logs of petroleum tests enabled making a structure-contour map on top of the uppermost Blaine gypsum beneath the Project Area. This enabled us to prepare a cross section and risk map showing the depth to the top of gypsum, and enables us to determine sites where the risk due to gypsum karst would be low. We believe that those locations where the depth to gypsum is at least $25 \mathrm{~m}$ would be low-risk sites. We believe that the risk would be moderate where the depth to gypsum is between 6 and $25 \mathrm{~m}$. The gypsum-karst risk would be high at those locations where gypsum is less than $6 \mathrm{~m}$ deep.

We suggest further evaluation of the potential for gypsum karst in the Watonga area by considering the following actions: 1) examine cores drilled through the Shimer Gypsum Bed in the Project Area to determine if there is evidence of dissolution in that shallowest and thickest gypsum bed; 2) conduct a survey of landowners within the Project Area to determine if any collapse structures, similar to Foley sink, have formed recently; 3) if such a collapse structure is reported by landowners, it should be examined by field work and core drilling to see if it is underlain by gypsum-karst features; and 4) conduct a survey of landowners where the Blaine Formation crops out just east of the Project Area, to determine if they have observed any karst-like features that might indicate gypsum dissolution.

\section{References}

Alger RP, Crain ER. 1966. Defining evaporite deposits with electrical well logs. In: Rau JL, editor. Second symposium on salt. The Northern Ohio Geological Society, Inc., vol. 2, p. 116-130.

Bozeman J. 2003. Exploration of western Oklahoma gypsum caves. In: Johnson KS, Neal JT, editors. Evaporite karst and engineering/environmental problems in the United States. Oklahoma Geological Survey Circular 109. p. 57-64.
Fay RO. 1958. A recent sink hole in central Blaine County, Oklahoma. Oklahoma Geology Notes 18: 58-64.

Fay RO. 1964. The Blaine and related formations of northwestern Oklahoma and southern Kansas. Oklahoma Geological Survey Bulletin 98. 238 p.

Fay RO. 2010. Preliminary geologic map of the Watonga 30' X 60' quadrangle, Blaine, Caddo, Canadian, Custer, Dewey, and Kingfisher Counties, Oklahoma. Oklahoma Geological Survey, Oklahoma Geologic Quadrangle Map OGQ-77A. Scale, 1:100,000.

Fay RO, Ham WE, Bado JT, Jordan L. 1962. Geology and mineral resources of Blaine County, Oklahoma. Oklahoma Geological Survey Bulletin 89. 258 p.

Johnson KS. 1967. Stratigraphy of the Permian Blaine Formation and associated strata in southwestern Oklahoma [PhD dissertation]. Champaign (IL): University of Illinois. $247 \mathrm{p}$.

Johnson KS. 1985. Structure contour map and stratigraphic/hydrologic data on the Blaine aquifer in the Hollis Basin of southwestern Oklahoma. Oklahoma Geological Survey Open-File Report. Scale 1:125,000.

Johnson KS. 1989. Geology of Jester [gypsum] Cave [Blaine Formation, southwestern Oklahoma]. NSS News, National Speleological Society, Huntsville, AL 47 (1): 11-17.

Johnson KS. 1990. Hydrogeology and karst of the Blaine gypsum-dolomite aquifer, southwestern Oklahoma. Oklahoma Geological Survey Special Publication 90-5. 31 p.

Johnson KS. 1993. Dissolution of Permian Salado salt during Salado time in the Wink area, Winkler County, Texas. In: Love DW, and others, editors. Carlsbad region, New Mexico and west Texas. New Mexico Geological Society Guidebook, 44th Annual Field Conference. p. 211-218.

Johnson KS. 2003a. Evaporite-karst problems in the United States, In: Johnson KS, Neal JT, editors. Evaporite karst and engineering/environmental problems in the United States. Oklahoma Geological Survey Circular 109. p. 1-20.

Johnson KS. 2003b. Evaporite karst in the Permian Blaine Formation and associated strata of western Oklahoma. In: Johnson KS, Neal JT, editors. Evaporite karst and engineering/environmental problems in the United States. Oklahoma Geological Survey Circular 109. p. 41-55. 
Johnson KS. 2003c. Regional mapping of karst terrains in Oklahoma for avoidance of engineering and environmental problems. In: Johnson KS, Neal JT, editors. Evaporite karst and engineering and environmental problems in the United States. Oklahoma Geological Survey Circular 109. p. 113-117.

Johnson KS. 2008, Evaporite-karst problems and studies in the USA. Environmental Geology 53: 937-943.

Martinez JD, Johnson KS, Neal JT. 1998. Sinkholes in evaporite rocks. American Scientist 86 (1): p. 38-51.

Miser HD. 1954. Geologic map of Oklahoma. US Geological Survey and Oklahoma Geological Survey. Scale 1:500,000.

Myers AJ, Gibson AM, Glass BP, Patrick CR. 1969. Guide to Alabaster Cavern and Woodward County. Oklahoma: Oklahoma Geological Survey Guidebook 15. 38 p. 


\section{SINKHOLES AND THE ENGINEERING AND ENVIRONMENTAL IMPACTS OF KARST}

\section{PROCEEDINGS OF THE THIRTEENTH MULTIDISCIPUNARY CONFERENCE}

\section{May 6 through 10, 2013 Carlsbad, New Mexico}

\section{EDITORS:}

Lewis Land

New Mexico Bureau of Geology and Mineral Resources

and National Cave and Karst Research Institute

Daniel H. Doctor

U.S. Geological Survey

J. Brad Stephenson

$C B \& I$

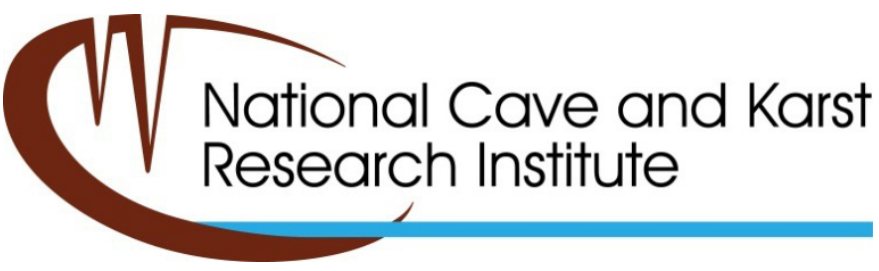

